\title{
Classroom Interaction in English Reading Class
}

\author{
Rizka Safriyani \\ English Teacher Education \\ UIN Sunan Ampel Surabaya \\ rizkasafriyani@uinsby.ac.id
}

\begin{abstract}
Language classrooms have different techniques and discourse used compared to nonlanguage subject classroom. The interaction between teacher and students is also interesting to be examined. Therefore, the purpose of this study is to describe the structure of classroom interaction in reading class and to indentify the act used in the interaction to maintain the interaction in a reading class.

Descriptive qualitative research is applied in this research. Thirthy seven students and one lecturer of English Reading Class at English Teacher Education Department at State Islamic University of Sunan Ampel Surabaya are involved in this study. Observation checklist, video, field note and interview guide are used as the instruments of the research.

The result shows that the structures of interactions in a reading class are mainly Initiation Response (IR). IR seems to be more dominant than Initiation Feedback (IF). The acts occur in the interactions within a reading class are 15 acts, they are: el (elicitation), rep (reply), m (marker), n (nomination), ms (metastatement), d (directive), rea (react), ch (checking), ack (acknowledge), i (informative), $\wedge$ (silent stress), con (conclusion), com (comment), e (evaluate), acc (accept). Those acts are spread either in opening section, answering section, following up, framing, or in focusing.
\end{abstract}

Keywords-classroom interaction, reading class, act

\section{INTRODUCTION}

Speaking and listening are spent more in the teachinglearning process. Those typically take a large portion of time than written discourse. Since speaking as a form of spoken discourse is one of the basic media for creating classroom interaction, it may play crucial role in the process of students' development. Yani Zhang states the quality of students learning is closely connected with the quality of classroom discourse [1]. It may happen since the message or the idea presented in classroom discourse is the focus for achieving communication aim, especially in teachinglearning purpose. Thus, when the focus of communication (message idea) is not achieved, it will produce communication breakdown which in turn will bother students' understanding about what the teacher has said. Consequently, it can influence students' quality of the learning process.

Regarding that case, it can be said that classroom discourse is important to know and to study, especially by a teacher. Therefore, to do analysis of classroom discourse is felt very significant, especially for language teaching since the main aim of language teaching is the language itself. By applying discourse analysis in the classroom, teacher can know the pattern of communication differences in each different classroom activity and different groups of people. As a result, both teacher and students can potentially develop their mutual understanding. Furthermore, by applying classroom discourse analysis in the class, teacher can also promote students to interact and can provide opportunities for students to engage in talk. Reading activities is one of the most important processes to give language input to the students. In Teaching Reading class mainly asks students to read a lot of text to develop their comprehension, skill and knowledge as well. Therefore, the interaction between teacher and students within reading class will mainly interesting to be analyzed so that readers can get a description about the classroom interaction structure and the impact of each teachers' talk to the students.

The paper discusses the structure of classroom interaction by having a close look at the utterances produces by lecturers and students in the teaching and learning process. The study on classroom interaction will bring better understanding on how professional teachers should maintain their interactions in the classroom to apply students centered learning. The paper, then, proposes some implications of the findings, in particular, toward the teaching of English in a reaading class.

\section{CLASSROOM INTERACTION IN ENGLISH READING CLASS}

\section{A. CLASSROOM DISCOURSE}

Classroom discourse refers to the language that teachers and students use to communicate with each other in the classroom. The earliest systematic study of classroom discourse was reported in 1910 and used stenographers to make a continuous record of teacher and student talk in high school classrooms. The first use of audiotape recorders in classrooms was reported in the 1930s, and during the 1960s there was a rapid growth in the number of studies based on analysis of transcripts of classroom discourse[2].

In terms of discourse analysis studies, Classroom Discourse looks at the relationship between language, interaction and learning. Providing a comprehensive account of current perspectives on classroom discourse, Walsh makes the case for a need not only to describe classroom discourse, but to ensure that teachers and learners develop the kind of interactional competence which will result in more engaged, dynamic classrooms where learners are actively involved in the learning process.

As one of the most useful ways to help teachers develop and improve their professional practices, discourse can be 
placed at the centre of the teaching and learning process. By helping teachers understand interactional processes and by getting teachers to study their own use of language and its effects on learning, it is possible to greatly enhance microscopic understandings of classroom processes, thereby improving the quality of both teaching and learning.

\section{B. Classroom Interaction in Teaching Reading}

Teaching is an interactive act, whereas interaction is the communication among teacher and students which run continuously as responsive acts. Teaching Reading is different from teaching other language skills. Seeing the quiet seems to be the indicators of learning taking place. Reading classes are often very quiet. On the other hand, Teaching reading plays an important part because teaching reading can give readers a model of a good writing. Therefore, looking at the interaction happened in a reading class is important.

Tickoo stated that in classroom interaction and classroom activities can be described as follows: The teacher interacts with the whole class, The teacher interacts with a group, a pair or an individual pupil, Pupils interact with each other: in groups, in pairs, as individuals or as a class and Pupils work with materials or aids and attempt the task once again individually, in groups and so on. Sinclair and Coulthard promoted a tool to study classroom discourse, concentrating mainly on interaction between the teacher and individual students. Figure 1. ilustrates the IRF Model.

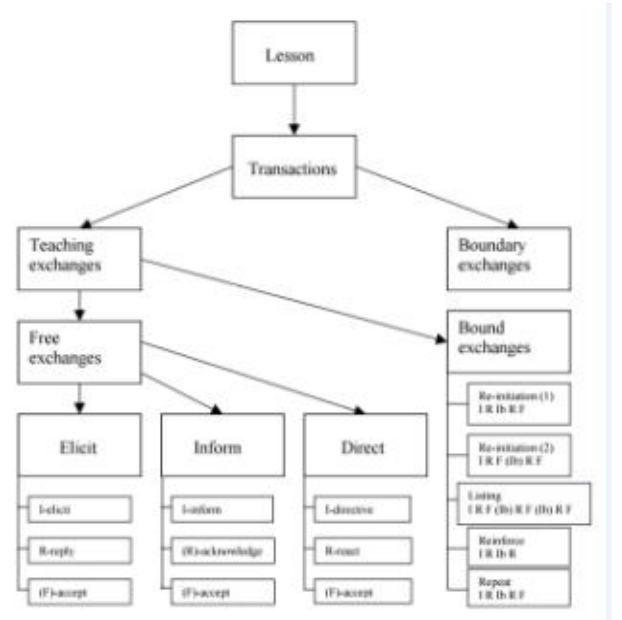

Fig 1 Sinclair And Coultard IRFModel

Sinclair and Coulthard discovered that language in the classroom followed a very rigid sequence, and that speaking patterns were highly structured. Thus, in creating a structural description of discourse, speech acts found in the classroom could be defined according to their function. McCarthy supports this theory and claim that this tool is useful for analyzing patterns of interaction where talk is relatively structured and should be suitable for to one to one classroom.

The ranking scale of the Discourse Analysis model contains 4 components. They are, in descending order of hierarchy: transaction, exchange, move and act. The structure of transaction consists of units of exchanges, exchange units of moves, and move units of acts. Furthermore, teaching exchanges consist of initiation moves, response moves(the answering move), and followup moves. This three-move structure of an exchange (IRF) is commonly cited. IRF structure is characteristic of teacher-led discourse, in which the teacher asks a question or provides information, the student responds or reacts, and the teacher provides some degree of comment or evaluation. This paper describes the structure and the act of the lecturer and students in English Reading Class to explain the interaction.

\section{RESEARCH METHOD}

The study used descriptive qualitative analysis. Teacher utterances and students utterances were recorded from the audio recorder by the observer for two meetings. The audio then were transcribed into doc format. Some irrelevant data were reduced to avoid ambiguity. Next, coding was done to ease the data analysis. The transcription was analyzed and classified based on the Exchange, move, and the acts structure of the interaction. Classifiying the move, the data then classified based on the act of the utterances. The data collected constitute a varied range of options of how real teachers orchestrate classroom talk. Classification table were used to specify the exchange, the move and the acts. Classifiying the data, the writer visualized the result of the analysis into some figures to describe the most common exchange, move and acts within The English Reading Class. From the analysis of the recordings and transcripts, it becomes obvious that some teachers, whether knowingly or instinctively, consistently create opportunities for learner involvement because the language they use matches the pedagogic purpose they have in mind. Out of the eight recorded lesson extracts provided by teacher, this extract can serve as a model for self-reflection and application for other teachers. Most of the examples provided in the discussion that follows have been taken from this particular extract. findings and discussion. 


\section{FINDINGS AND DISCUSSION}

The result shows that the structures of interactions in a reading class are mainly Initiation Response (IR). IR seems to be more dominant than Initiation Feedback. There are $63 \%$ of initiation response structures, $26 \%$ initiation feedback structures and $11 \%$ initiation response feedback structures among the total number of the interaction.

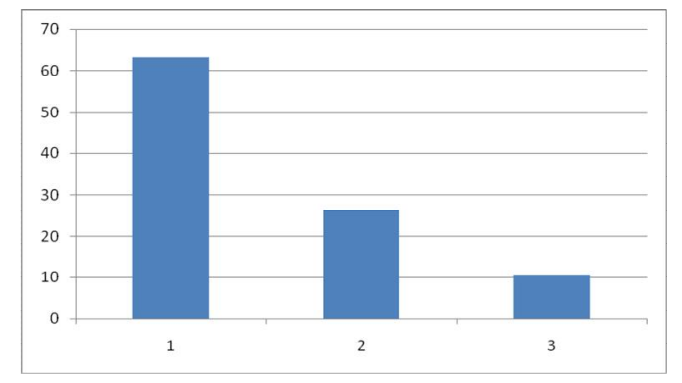

Fig 2 Percentage of Initiation Response, Initiation Feedback and Initiation Response Feedback in English Reading Class

Moreover, 90 percent of the initiation comes from the lecturer. Lecturer elicits and direct questions to the students. Only 10 percents of the initiation comes from the students. Students ask questions about the final examination and then the lecturer responses students' questions with a brief answer. Students also elicit about the paragraph written for the summary exercise.

There are 17 opening, 19 answering, 3 framing, 2 focusing and 3 following up moves happened in English reading class. The percentage of the move is presented below:

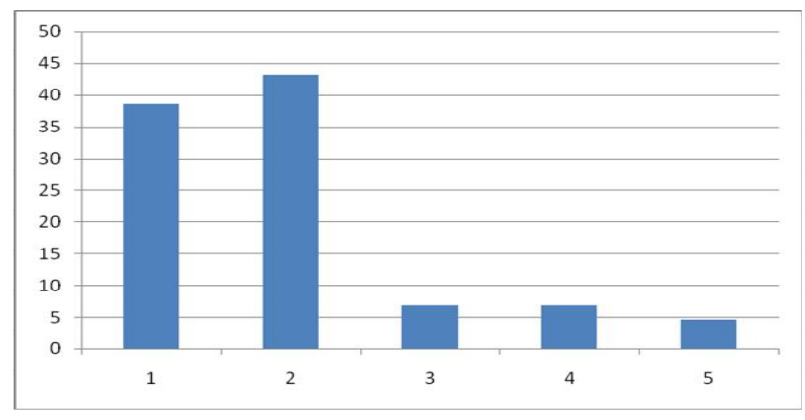

Fig 3 Percentage of Move in English Reading Class

From the figure above, answering move is the highest move within the interaction. There are 4 major acts included in answering move. Acknowledge, reply, react and comment are the four acts commonly done within the interaction on the answering move. On the other hand, there are 8 major acts happened in opening moves. Marker, starter, elicitation, directive, informative, check, prompt, clue and nomination are the acts found in the opening move of an English Reading
Class. Within all the moves, there're 76 acts occurs in English Reading Class. The acts occur in the interactions within a reading class are 15 kinds of acts, they are: el (elicitation), rep (reply), m (marker), n (nomination), ms (metastatement), d (directive), rea (react), ch (checking), ack (acknowledge), i (informative), $\wedge$ (silent stress), con (conclusion), com (comment), e (evaluate), and acc (accept). Those acts are spread either in opening section, answering section, following up, framing, or in focusing. Related to the frequency of the act, reply acts is the most dominant acts occur with in the English Reading Class. The distribution of the act frequency are presented below:

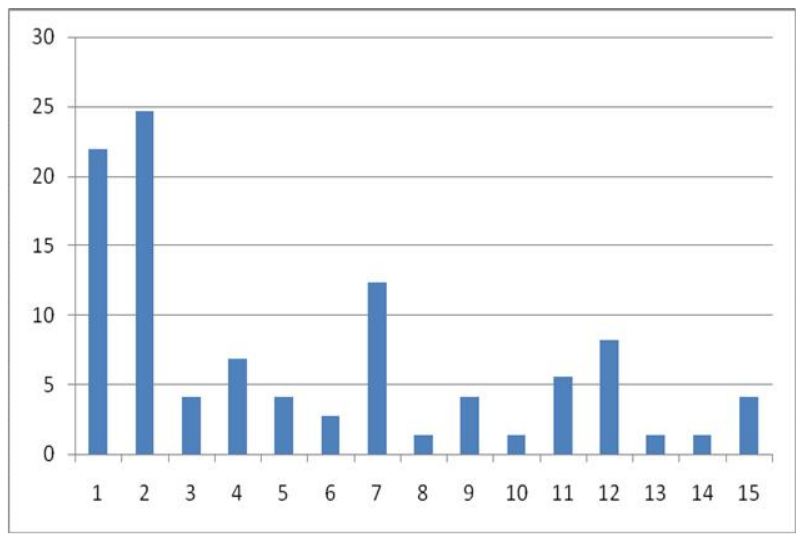

Fig.4 Percentage of Acts in English Reading Class

From the figure above, reply acts and elicitation acts has the the highest percentage within the interaction. This is in line with the previous description where the answering move is higher than opening moves. Answering moves is made up reply acts. In reply acts, student usually participates in classroom activities. Students answer teachers' questions and give response to the teachers instruction.

\section{A. Initiation Response and Initiation Feedback Structure}

IRF Communication pattern has been commonly used in education. IRF is the turn sequence of interaction pattern in the classroom. The first turn is the initiation of the conversation, the second turn is the response and the third turn is the follow up response.This pattern begin with either the lecturer or students initiating a topic or asking a question. In this context, the main activity occurred in English reading classroom are presentation and discussion. Students were asked to write a critical review summary of an academic journal and then they presented in turn. Students presented their work in group and the other group would ask some questions. After finishing the presentation and the discussion, teacher and students mainly do eliciting which feedback is given by the teacher for students. 
Some fragments of the analysis are presented in the extract below:

Extract 1

Lecture

Student 1

Student 2

Lecturer

Students 1
There are two major moves, opening and following up. In Extract 2, there are one openings and one following up move. Moreover, on extract 2 there are elicitation acts and reply act.s The two extracts show two different pattern of classroom interaction. The first extract shows the initiation response structure and the secons extract shows the initiation feedback structure. The result of the observation shows that initiation response pattern is more dominantly used.

In reading activity, it is found that feedback is rarely given because most of the activity is based on the lecturers' guide. The presentation session is limited, therefore the structure of interaction may come with a homogeneus pattern namely initiation response.

Extract 1 begins with the Lecturers' initiating the questionanswer sequence by saying, "Last week I have asked you individually to find an article summary and bring today, right?, Heemh, Do all of you do your job?". S1 starts to response "Yes Mom. We got it" and they're showing their paper, and then continues with S2 "Yes.." . Next, the lecturer continues the instruction to ask her students to go to their group and decide the speakers' turn within their group. Then, Students response the lecturer's instruction by saying yes mom.

In this extract, lecturer initiates the interaction by framing and focusing move which checks whether students have done their work to find and to bring article summary or not. Students start to respon by answering questions. The first students reply what the teacher has instructed for deciding the presenters' turn-taking. The second students reply the instruction to respon teachers' checking questions. Next, the lecturer continues the initiation by giving another instruction to control the next activity. Students respond the teacher' instruction to start to decide about who will be the $1^{\text {th }}, 2^{\text {th }}, 3^{\text {th }}, 4^{\text {th }}$ speaker.

There are two major moves, opening and answering. In Extract 1, there are two openings and three answering move. Moreover, on extract 1 there are checking act, reply act, react act, and directive act.

On the other hand, extract 2 shows different pattern of classroom interaction in reading class.

Extract 2

Student 1

: "Mom is the summary separated for each part or directly to the whole parts of the articles?"

Teacher : :You can do the summary directly. Please do it with your own words"

Extract 2 begins with the initiation of the question-answer sequence by saying, " Mom is the summary separated for each part or directly to the whole parts of the articles? Next, the lecturer gives feedback by saying "You can do the summary directly. Please do it with your own words"

In this extract, student 1 initiates the interaction by opening move. Students elicit the teacher to ask question dealing with the paragraph that they should make for summary part.

Next, teacher gives feedback on the students' question by providing an answer with some emphasis on the originality of the document.

\section{B. Move and Act in Classroom Interaction}

Acts are the smallest and "...lowest rank of discourse" [3]. When a teacher can transfer the information or ideas, elicit the questions, and provide feedback clearly, appropriately, and effectively, it will influence students' ability as well to process the teacher's talk which in turn, it will impact on how well students can develop their achievement. On the contrary, when teacher's ability in transferring the messages, asking the questions, and giving comment is not good enough, it will also impact on the students' learning development.

In relation with the result above, teacher transfers her idea in a simple way. Most structures are in the form of Initiation Response structure.

This is inline with Yuqi's study in Winarti which shows teacher to give directions, explain activities and check students' understanding [4]. Similar research findings done by Farahian reports that most of teacher talks were used to elicit students' knowledge (questions) which were classified under three categories, namely procedural, convergent, and divergent[5].

Classroom discourse is dominated by question and answer routines, with teachers asking most of the questions, while learners ask correspondingly few questions. It is by asking questions that teachers are able to control the discourse, especially given that they know the answers to most of the questions they ask. As the example, when the teacher ask another students about the content of the introduction. Actually, teacher knows the answer to the questions they ask but teacher has another purpose to check another students' understanding. This is in line with Walsh statements about teacher questions which serve a range of functions, including eliciting a response, checking understanding, guiding learners towards a particular response, promoting involvement and concept checking [6]. While it is true to say that conversations in the classroom frequently have a three-part structure, speakers do not usually evaluate one another's performances. Sometimes speakers do not expect a linguistic response. It can be seen from the result of the analysis which show some non verbal response are given by the students. They directly do the instruction when they are asked to meet their group.

The IRF sequence enables us to understand interaction in the classroom, and comprehend its special nature. An awareness that a major portion of class time is employed by the 
of IRF enables us to consider how we might vary interaction more and introduce alternative types of sequence. Teacher has to realize that they tend to give initiation and feedback or evaluation in a classroom interaction. It should be followed with an understanding about how to manage teacher talk time so that teacher centered activities will not be the case in language teaching. The basic argument is that teachers can do much to improve their professional practice and enhance learning by studying their own interactions with students. By looking at the moment-by-moment management of turns and topics we can see, in the interaction, what is being learnt, what is not being learnt, what is the relationship between what teachers teach and what learners learn

\section{CONCLUSION AND IMPLICATION FOR THE TEACHING PROCESS}

\section{A. Conclusion}

The structures of interactions in a reading class are mainly Initiation Response (IR). The acts occur in the interactions within a reading class are 15 acts, they are: el (elicitation), rep (reply), m (marker), n (nomination), s (starter), ms (metastatement), d (directive), rea (react), ch (checking), ack (acknowledge), i (informative), ^ (silent stress), con (conclusion), com (comment), e (evaluate), acc (accept), b (bid). Those acts are spread either in opening section, answering section, following up, framing, or in focusing. Reply acts seems to be more dominant than elicitation since both actually considered as the response of the initiation.

\section{B. Implication for the Teaching Process}

Discourse patterns can be identified at the small-scale level of the individual acts, and the larger-scale level of exchanges. Rather than looking at each word or phrase separately, these labels can highlight communicative patterns found in the discourse. This can determine the type of structure within the discourse and how it is organized.

Examining discourse through Sinclair and Coulthard's model can provide a better understanding of the roles of the teacher and students, and how these roles are created and maintained by the language used. By observing the roles through the discourse, we can see how teachers and their students use language in order to interact. Once teachers understand how their language affects their role in the classroom they can begin to use language more consciously.

\section{Acknowledgment}

Rizka Safriyani thanks to Faculty of Education and Teacher Training, State Islamic University of Sunan Ampel Surabaya for providing the department to do the research.

\section{References}

[1] Yani Zhang. Classroom Discourse and Student Learning.in Asian Social Science, Year 2008, Vol.4, No.9 retrieved from http://www.ccsenet.org/journal/index.php/ass/article/viewFile/1078/103 8

[2] Graaham Nuthal et all. Classroom Discourse, Cognitive Perspective Year 2017, Retrieved from http://education.stateuniversity.com/pages/1916/Discourse.html

[3] Andrew White. The Application Of Sinclair And Coulthard's Irf Structure To A Classroom Lesson: Analysis And Discussion : A Module Four Assignment Classroom And Spoken Discourse/ Written Discourse University Of Birmingham, England, Year 2003, retrieved from https://www.birmingham.ac.uk/Documents/collegeartslaw/cels/essays/csdp/DailySDAnAnalysisofClassroomDiscourseThe UsefulnessofModule4AssessmentTask.pdf

[4] Winarti. Classroom Interaction: Teacher and Student Talk in International Class Program (ICP) in LSCAC Conference Proceedings The 4th International Conference on Language, Society and Culture in Asian Contexts (2016), Volume 2017. Retrieved from https://knepublishing.com/index.php/Kne-Social/article/view/742/2161

[5] Rezaee M., Farahian M., An exploration of discourse in an EFL classroom, Teacher talk. Procedia - Social and Behavioral Sciences, Year: 2012, Volume: 47, Page: $1237 \quad-1241$. DOI: $\underline{10.1016 / \text { i.sbspro. } 2012.06 .806}$

[6] Steve Walsh. Classroom Discourse and Teacher Development. Edinburgh University Press. Year: 2013

[7] Rashidi N., Rafieerad M., Analyzing patterns of classroom interaction in EFL classrooms in Iran, Journal of Asia TEFL, Year: 2010, Volume: 7, Issue: 3 , Page: 93 -120.

[8] Szendroi I., Teacher talk in the ESP classroom: The results of a pilot observation study conducted in the tourism context, WoPaLP, Year: 2010, Volume: 4

[9] Bruner, J. Acts of meaning. Cambridge, MA: Harvard University Press. Year 1990

[10] Cazden, C. Classroom discourse. In M. E. Wittrock (Ed.), Handbook of research on teaching New York: Macmillan. Year 1986. Page. 432-463.

[11] Cohen, E. Restructuring the classroom: Conditions for productive small groups. Review of Educational Research Year 1991. Page: 1-35.

[12] Cole, M., \& Griffin, P. Cultural amplifiers reconsidered. In D. Olson (Ed.), The social foundations of language and thought: Essays in honor of Jerome S. Bruner, New York: Norton, Year : 1980 (pp. 343-364).

[13] Collins, A., Brown, J., \& Newman, S. Cognitive apprenticeship: Teaching the crafts of reading, writing and mathematics. In L. Resnick (Ed.), Knowing, learning and instruction: essays in honor of Robert Glaser (pp. 453-494). Hillsdale, NJ: Lawrence Erlbaum. Year 1989.

[14] Delamont, S. Interaction in the classroom, Contemporary sociology of the school. Suffolk: Richard Clay Ltd. Year 1976.

[15] Draper, S., \& Anderson, A. The Significance of Dialogue in Learning and Observing learning. Computers and Education, Year 1991. 93-107.

[16] Edwards, A. \& Westgate, D.Investigating Classroom Talk (2nd ed.). Basingstoke: Falmer Press. Year: 1994

[17] Fisher, E.Distinctive features of pupil-pupil classroom talk and their relationship to learning: How discursive exploration might be encouraged. Language and Education, Year: 1993, 7(4), 239- 257.

[18] Forrester, M. A conceptual framework for investigating learning in conversations. Computers and Education, Year : 1991, 17(1), 61-72.

[19] Vygotsky, L. S. . Thought and language (E. Hanfmann and G. Vakar, Eds. and Trans.). Cambridge, MA: MIT Press. Year: 1962

[20] Vygotsky, L. S. Mind in society: The development of higher mental processes (M. Cole, v. John-Steiner, \& E. Souberman, Eds.). Cambridge, MA: Harvard University Press. Year: 1978 